\title{
EENIGE OPMERKINGEN OVER HET IJZEREN-VOORRAADSTELSEL
}

door Drs L. G. Westermann

Door Prof. Polak zijn in de „Naamlooze Vennootschap" eenige artikelen gewijd aan de theorie van den zgn. ,ijzeren voorraad". ${ }^{1}$ ) In de door Prof. Polak ontwikkelde theorie wordt deze voorraad gezien als een permanent productie-middel, dat complementair is verbonden met de geheele outillage en de organisatie van het bedrijfscomplex, waartoe deze behoort.

Deze zienswijze leidt er toe, dat de bedrijfswaarde van den ijzeren voorraad geen verband behoeft te houden met de ruilwaarde of de vervangingswaarde van de goederen, waaruit deze voorraad is samengesteld.

In onderscheidene voorbeelden wordt de rol van deze ijzeren voorraad in de calculatie toegelicht, o.a. op pag. 222 (.,N.V." van 15 Nov.)

Begin voorraad A ... 20.000.- Verkoopen A ........ 30.000.Vervang. koopen B 25.000.- Eindvoorraad B ..... 20.000.Winst …........... 5.000.

$$
\text { 50.000.- }
$$$$
50.000
$$

De beginvoorraad A wordt door den eindvoorraad B (welke tegen dezelfde prijzen is gewaardeerd) geneutraliseerd, zoodat tegenover de plaatsgevonden verkoopen de vervangende aankoopen van partij B. moeten worden gesteld.

Prof. Polak karakteriseert het ijzeren-voorraadstelsel als een eenvoudige practische toepassing van het vervangingskoopstelsel, daar het evenals dit laatste systeem als winst beschouwen wil het verschil tusschen de opbrengst door verkoop en de kosten van den vervangingskoop. (zie p. 221, ,N.V.", 15 Nov.)

Het loont m.i. de moeite na te gaan of inderdaad dit principe van winst-berekening dezelfde beteekenis voor het bedrijfsleven kan worden toegekend als de $\mathrm{zgn}$. vervangingswaarde-calculatie (in de theorie van Prof. Limperg). Bij nadere beschouwing vallen principieele verschilpunten op, vooral wat de beteekenis aangaat als richtinggevend beginsel voor de practijk. Hoewel uiterlijk - wat winstcalculatie betreft - dezelfde resultaten kunnen worden bereikt bij deze beide methoden, is de wijze van verkrijging van deze winstcijfers geheel verschillend. Het ijzerenvoorraad-stelsel is een systeem, waarbij achteraf het finantieele resultaat van een bepaalde bedrijfsperiode wordt gecalculeerd. De theoretische fundeering van deze calculatie-methode wordt verkregen door den voorraad als duurzaam onderdeel van een onveranderd complex te zien, als onmisbaar element complementair verbonden met de andere deelen van het bedrijf.

Dezen starren voorraad kan inderdaad dit instrumentaal karakter niet worden ontzegd, maar het is m.i. niet in te zien, waarom uit deze visie op den voorraad in het bedrijfsproces de conclusie noodzakelijk is, dat wisselingen in de waarde van de samenstellende deelen van den voorraad, geen direct effect moeten hebben op de berekening van waarde en winst in het bedrijf. Bij de vervangingswaarde-calculatie wordt in eerste instantie een grondslag gelegd voor de waardeering der goederen ge-

1) Zie o.a. de „Naamlooze Vennootschap" van 15 November en 15 December 1940.

$\mathrm{m}$ a b blz, 102 
durende den bedrijfsgang en wel op het critische moment hierbij: de ruil van het product. Deze basis voor de waardeering der goederen is gevonden op grond van een causale analyse, welke de goederen-beweging in het continueele productie-proces als uitgangspunt heeft. Het ijzerenvoorraad-stelsel geeft echter geen richtlijn voor het handelen van den producent. Dit stelsel geeft meer een ,uiterlijk" ordeningsprincipe aan: het is een voorbeeld van administratieve techniek. Het hierbij verkregen winstcijfer is niet als bij de vervangingswaarde-calculatie als het ware "organisch" uit het bedrijfsproces voortgevloeid. Door deze methode van winst-calculatie verkrijgt men niet - in tegenstelling met de theorie van de vervangingswaarde - een juist inzicht in de rentabiliteit van het bedrijf, daar hierbij niet zuiver worden onderscheiden de resultaten, verkregen door den goederenruil en de gevolgen, voortvloeiend uit het houden van voorraden.

Op pag. 224 geeft Prof. Polak een cijfer-voorbeeld, waarbij de verschillen in calculatie-methode aan het licht kunnen worden gebrazht. Prof. Polak stelt een geval van inkrimping van den omzet en van den voorraad door schaarschte, gepaard gaande met prijsstijging (hoewel men wel herstel op de "oude" voorraad-basis tot de mogelijkheden rekent.)

Jaar I (ontstaan der schaarschte)

IJzeren voorraad A

1000 voor ...... f 10.000 .

Aankoop B

800 a 12 ....... , 9.600.-

Winst ….......... " $\frac{1.000 .-}{f 20.600 .-}$

Verkoop A

1000 a $13 \ldots \ldots$ f.... f $13.000 .-$

Voorraad B

800 voor.......

, 7.600.-

20.600

De voorraad $B$ wordt als volgt bepaald:

\begin{tabular}{|c|c|}
\hline $\begin{array}{l}\text { ijzeren voorraad } 1000 \text { voor } \ldots \ldots \\
\text { manco } 200 \text { à } 12 \ldots \ldots \ldots \ldots \ldots \ldots \ldots\end{array}$ & $\begin{array}{l}f \quad 10.000,- \\
, \quad 2.400 .\end{array}$ \\
\hline aanwezige voorraad 800 voor ... & 7.600. \\
\hline
\end{tabular}

De calculatie op basis van de vervangingswaarde komt tot dezelfde bedrijfswinst. Op het moment van den ruil der 1000 eenheden tegen $f$ 13.- wordt als kostprijs gecalculeerd $f$ 12. - per stuk, indien ten minste op dit moment de vervangingsprijs dezelfde was als die, waartegen de werkelijke aankoop van 800 eenheden à $f$ 12. - heeft plaats gevonden. Hier treedt een verschil aan het licht. Bij het ijzeren-voorraadstelsel wordt het bedrijfsresultaat, op grond van de feitelijke plaatsgevonden transacties berekend. Bij de vervangingswaarde-calculatie realiseert men zich bij den afzet der producten de waarde-wijzigingen, welke op de markt hebben plaatsgevonden van de zich in het bedrijf bevindende activa.

Bij een prijsdaling van de grondstof dalen de vervangingskosten van de grondstoffen-eenheden in voorraad, hetgeen onmiddellijk invloed heeft op de te berekenen kostprijzen. Hierdoor wordt het bedrijfsresultaat direct gesplitst in een gedeelte, hetwelk uit het eigenlijke ruilproces is verkregen en in een gedeelte, dat uit de voorraad-positie moet worden afgeleid.

Bij den verkoop - met als kostprijs $f$ 12. - per eenheid - wordt de ,prijsverschillen-rekening" gecrediteerd voor $f$ 2000.-. Deze reke- 
ning fungeert als ,,klem" om het bepaalde, in het bedrijf binnenkomende vermogen, uit hoofde van de prijsstijging der grondstoffen, vast te houden, daar dit vermogen niet voor uitkeering in aanmerking komt. Deze calculatie bij den ruil heeft als nevengevolg het scheppen van deze ,prijsverschillen-rekening", hetgeen bij het ijzeren-voorraad-stelsel, daar hier niet de waardeering der goederen op bepaalde critische momenten in het bedrijfsproces plaats vindt, niet kan worden waargenomen.

Op het einde van deze periode ontstaat nog een economische vervangingsverplichting van 200 eenheden. Het niet-samenvallen van de momenten van ruil en vervanging werpt hier een speciaal probleem op. daar het bedrijfsresultaat nog mede moet worden bepaald door deze vervangingsverplichting. Bij het balans opmaken moet een plaatsvindende prijsstijging der grondstoffen, na het moment van den ruil, alsnog door reserveering worden gedekt, indien ten minste vervanging nog niet heeft plaats gevonden. In het ijzeren-voorraad-stelsel komt niet tot uitdrukking welke grootheid als kostprijs bij den ruil is geintroduceerd. Vandaar, dat ook de invoering van een ,.prijsverschillen-rekening" niet aan de orde komt. In bovenstaand cijfervoorbeeld is de boeking in het credit van deze rekening voldoende om vervanging der resteerende 200 eenheden tegen den prijs van $f$ 12. - mogelijk te maken, daar bij den afzet van de 1000 eenheden, als kostprijs $f 12 .-$ is gecalculeerd.

Prof. Polak komt in het volgende jaar tot de volgende calculatie Jaar II

Voorraad B

800 voor ........ f $7.600 .-$

Aankoop C

1000 à $10 \ldots \ldots . . ., 10.000$.

Winst

$$
\begin{array}{rr}
, & 10.000 .- \\
, \quad 800 .- \\
\hline f 18.400 .- \\
\hline
\end{array}
$$

Verkoop B

800 a $10.50 \ldots$. f 8.400 .

IJzeren voorraad C

1000 voor

, 10.000.-

De totaal winst van $f$ 800. - ontstaat door een gunstig verschil bij den ruil van $800 \times 0.50=f 400$. - en een extra-winst, verkregen bij de aanvulling van den ijzeren-voorraad tot 10.000 eenheden van $200 \times$ $(12-10)=400$.

De vervangingswaarde-calculatie geeft, wat de prijs-en hoeveelheden mutaties betreft een veel reëeler beeld van het plaatsgevonden proces.

Bij den verkop van $f 800$. - eenheden a 10.50 ontstaat de boeking:

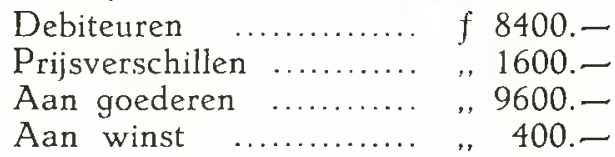

Als bedrijfswinst is dus $f$ 400.- gerealiseerd. Door het niet-samenvallen van het moment van den ruil in jaar I (verkoop van 1000 eenheden a $f(3 .-)$ met het moment van aanschaffing van de resteerende 200 eenheden, is een voordeel ontstaan, daar in deze periode een prijsdaling der grondstoffen heeft plaatsgevonden (van $f$ 12.- tot $f$ 10.per eenheid). Door dit uitstel van aankoop is inderdaad een winst verkregen, welke voor uitkeering in aanmerking komt. Het is echter van groot belang voor het inzicht in de rentabiliteit van het bedrijf, dat de 
winst, verkregen uit den afzet der producten, wordt onderscheiden van de voor- en nadeelen behaald met ".speculatie" met de voorraden.

Prof. Polak voert ook nog het begrip ,vrije" voorraad in voor dat gedeelte van den voorraad hetwelk incidenteel boven den ijzeren-voorraad aanwezig is. Daar bij verkoop van deze ,vrije" voorraden geen directe noodzaak tot vervanging bestaat, is het economisch verantwoord prijsveranderingen op dit gedeelte van de voorraden als winsten of verliezen te beschouwen. Dit lijkt mij juist gezien. En het is niet van belang ontbloot een overheidsmaatregel kort na de mobilisatie, waarbij het calculeeren van de vervangingswaarde aan het bedrijfsleven niet werd toegestaan, in het licht van deze theorie te beschouwen.

Deze maatregel moet men in eerste instantie beschouwen binnen het kader van de destijds abnormale marktverhoudingen. De reeds geruimen tijd dreigende internationale toestand had in vele bedrijven tot een sterk opvoeren van den voorraad aanleiding gegeven. Reeds hierdoor was een prijsverhoogende tendenz in het leven geroepen, welke bij vermindering van de versnelde aankoopen een verlaging te zien zou hebben gegeven. De voorraad-vorming was in die periode dan ook in belangrijke mate uit speculatieve overwegingen ontstaan. In normale omstandigheden worden de voorraden in de bedrijven, uit hoofde van kosten en risico hieraan verbonden, zoo klein mogelijk gehouden. Deze „normale" voorraden hebben hun specifieke functie in de onderneming, n.l. het opvangen van onregelmatigheden in de vraag en het waarborgen van een ongestoorden bedrijfsgang.

In die dagen was het vormen van ,vrije" voorraden vrijwel zonder risico, daar men alleen rekening behoefde te houden met een oploopende markt. De ondernemers, die uit speculatieve overwegingen to relatief groote voorraadvorming waren overgegaan, zouden nu bij calculatie van de vervangingswaarde inderdaad extra voordeelen op deze "vrije" voorraden hebben kunnen realiseeren, daar deze niet voor vervanging in aanmerking kwamen.

Wel ontstonden voor de bedrijven, welke alleen voorraden op „normale" grootte in het bedrijf hadden, bepaalde moeilijkheden, maar de toenmalige situatie bracht met zich mede, dat practisch ook geen vervanging van den , normalen" voorraad kon plaats vinden.

De economische constellatie bracht als het ware een ,structuur"-verandering, wat de voorraden betreft, met zich mede, waardoor de voorraad-posities der bedrijven verminderden.

Hoewel het uitschakelen van de vervangingswaarde-calculatie nadeelen voor het bedrijfsleven deed ontstaan, waren er eveneens argumenten, welke dezen overheidsmaatregel rechtvaardigden.

Ook bij de resultaten-berekening in de gevallen, waar ,vrije" voorraden aanwezig zijn, bereikt men met het ijzeren-voorraad-stelsel geen scheiding in zuivere bedrijfswinst en in voor - en nadeelen, verkregen door deze extra-voorraadvorming.

Dit stelsel lijkt mij dan ook geen deugdelijk instrument voor het bedrijfsleven, daar het geen steun biedt aan den producent, bij zijn waardeering van de goederen op de critische momenten in het bedrijf.

Eerst het vervangingswaarde-principe, als waarde-theorie geformuleerd, geeft een vasten grondslag voor de waardeering der goederen. daar nù bij den ruil rationeel kan worden gehandeld en een juist inzicht in de kosten kan worden verkregen. Het is m.i. dan ook niet juist het ijzeren-voorraad-stelsel op een lijn te plaatsen met de theorie der ver- 
vangingswaarde. Wel geeft dit systeem een duidelijke begrenzing van het gedeelte van den voorraad, hetwelk als "normaal" is te beschouwen, hetgeen van beteekenis moet worden geacht.

\section{EENIGE OPMERKINGEN OVER DE ONDERZOE- KEN DOOR RIJKSACCOUNTANTS TEN BE- HOEVE VAN DE BELASTING-ADMINISTRATIE}

door Drs D. Nye

In het Dec.-nummer 1939 1) van dit tijdschrift werden door mij eenige opmerkingen gemaakt over de onderzoeken door Rijksaccountants ien behoeve van de belastingadministratie. Ik stelde daarbij aan de orde de vraag of de Hooge Raad terecht aan den accountant dezelfde minimumeischen kon stellen als aan den Inspecteur en in verband daarmede kwam tevens ter sprake de vraag in hoeverre, na een door een belastingaccountant ingestelde contrōle nog feiten onontdekt konden blijven, waarop bij een tweede accountantsonderzoek wèl de vinger werd gelegd. Beide vragen werden door mij ontkennend beantwoord.

In de Juni-aflevering ${ }^{2}$ ) verschenen over dit onderwerp eenige beschouwingen van de Heeren De Blaey. Delmonte, Hageman en Van der Pauw, waarvan ik met belangstelling kennis nam. In deze artikelen zijn meerdere punten, die mij aanleiding geven tot een wederwoord. Daarbij zal ik op mijn uitgangspunt - het arrest van den Hoogen Raad van 28 November 1938 B.i.B. Nr. 6782 - niet anders dan terloops terugkomen en in hoofdzaak de volgende door de discussie aan de orde gestelde punten behandelen:

1e. de functie van den public accountant en van den accountant-beambte;

2e. de controleerende en adviseerende functie van den accountant;

3e. de investigation door den public accountant en het onderzoek door den belastingaccountant;

4e. de bijzondere functie van den public accountant en de beperkte functie van den accountant-beambte.

I. De functie van den public accountant en van den accountant beambte.

De tegen mijn beschouwingen ingebrachte bezwaren komen voor een groot deel tezamen op één punt: de functie van den Rijksaccountant is een andere dan die van den public accountant; het doel van de opdrachten aan den rijksaccountant is een andere da nvan die aan den public accountant, mitsdien hebt gij, collega Nye, ten onrechte den arbeid van den rijksaccountant gemeten met maatstaven geldende voor den arbeid van den public accountant.

Dit argument is zeer belangrijk. Inderdaad geldt voor den accountant, hetgeen voor iederen functionaris geldt: zijn taak wordt bepaald door zijn functie. Indien de functies verschillen, zullen ook de taken verschillend zijn. Inzooverre stem ik dus met de gegeven beschouwingen in.

Het probleem wordt dus teruggebracht tot de volgende vraag: laat het verschil in functie, zoo dit bestaat, tusschen belastingaccountant en

1) 16 den Jaargang.

2) 17 den Jaargang.

$\mathrm{m}$ a b blz. 106 